\title{
LIKE A BAD PENNY: THE PROBLEM OF CHRONIC OVERCROWDING IN THE PRISONS OF COLONIAL NATAL: 1845 TO 1910 (PART 1)
}

\section{Stephen Allister Peté*}

\section{Introduction}

Almost two decades after the end of apartheid, chronic overcrowding remains one of the most serious problems facing the South African penal system. For example, the most recent annual report of the Judicial Inspectorate for Correctional Services in South Africa states as follows:

The inmate population in South Africa has been characteristically one of the highest per capita in the world as has been written about in numerous publications including in the Inspectorate's Annual Reports. It is accepted that the over-population of inmates per available infrastructure is a problem in certain centres and then, within such centres, largely in the communal cells and, in some instances, single cells where inmates are "doubled-up" or even "tripled-up". These conditions are unacceptable and have been found to be so during our inspections around the country. ${ }^{1}$

1 Annual Report of the Judicial Inspectorate for Correctional Services for the period 1 Apr 2013 to 31 Mar 2014 at 37. (See website http://judicialinsp.dcs.gov.za/Annualreports/Annual\%20 Report\%202013\%20-\%202014\%20(2).pdf(accessed 22 Jan 2015).) Figures setting out the precise

* Associate Professor of Law, School of Law, Howard College Campus, University of KwaZuluNatal.

\section{UNISA $\cong$}

Fundamina

Volume 21 | Number 1 | 2015

pp 102-118
Doi: $10.17159 / 2411-7870 / 2015 / v 21 n 1 a 6$ Print ISSN 1021-545X/ Online ISSN 2411-7870

(C) Unisa Press 
Overcrowding is, quite simply, a scourge which bedevils efforts to ensure that imprisonment in South Africa is, at the very least, a humane form of punishment. At various times during the post-apartheid period the extent of overcrowding in South African prisons has been sufficiently serious so as to raise doubts as to the constitutionality of this form of punishment. In 2004, for example, Jonny Steinberg conducted research on behalf of the Centre for the Study of Violence and Reconciliation into prison overcrowding and the constitutional right to adequate accommodation in South Africa. At the outset of his paper detailing the results of his research he gave the following sobering assessment:

At risk of second-guessing a jurisprudence which is yet to emerge, it seems clear that the extent of overcrowding in South Africa's prisons places the incarceration of the vast majority of this country's inmates in violation of constitutional standards, no matter how low these standards are set. ${ }^{2}$

extent of overcrowding are not provided in the 2013/2014 report. An examination of the 2012/2013 report, however, reveals that during that particular year, the total South African prison population amounted to 153,049 prisoners, whereas the system as a whole was designed to accommodate just 119,890 persons (see the Annual Report of the Judicial Inspectorate for Correctional Services for the period $1 \mathrm{Apr} 2012$ to $31 \mathrm{Mar} 2013$ at 40. See website http://judicialinsp.dcs.gov.zal Annualreports/ANNUAL\%20REPORT\%202012\%20-\%202013.pdf (accessed 4 Feb 2015).) This means that South African prisons were approximately 128\% overcrowded during the 2012/2013 year. It is interesting to note that the total prison population in South Africa as at 31 Mar 2014 amounted to 154648 prisoners (Annual Report of the Judicial Inspectorate for Correctional Services for the period 1 Apr 2013 to 31 Mar 2014 at 38. See website http://judicialinsp.dcs. gov.za/Annualreports/Annual\%20Report\%202013\%20-\%202014\%20(2).pdf (accessed 22 Jan 2015).) It is further interesting to note certain comments made on $11 \mathrm{Feb} 2013$ by the Minister of Correctional Services, Sibusiso Ndebele. He was reported as stating that South Africa had the highest prison population in Africa and that the country was "currently ranked ninth in the world in terms of prison population, with approximately 160000 inmates". (See Mail \& Guardian Online available at http://mg.co.za/article/2013-02-11-south-africa-has-highest-prison-population-inafrica-says-ndebele (accessed 12 Feb 2013).)

2 J Steinberg Prison Overcrowding and the Constitutional Right to Adequate Accommodation in South Africa (Paper commissioned by the Centre for the Study of Violence and Reconciliation) Jan 2005 at 1. Steinberg went on to examine the space available in South African prisons as at

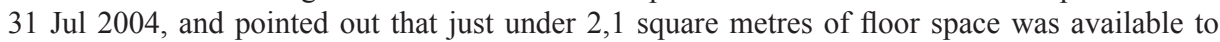
each prisoner confined in an average communal cell. He went on to point out that, in Europe, the Committee for the Prevention of Torture and Inhuman or Degrading Treatment or Punishment (CPT), the body charged with monitoring compliance to the European Convention for the Prevention of Torture and Inhuman or Degrading Treatment or Punishment, had set four square metres per prisoner in a communal cell as a bare minimum standard. This meant that, at the time in question, "the average South African prisoner in a communal cell thus occupies just over half the floor space considered a bare minimum in the CPTs jurisdiction" (at 2). Steinberg pointed out that, although the constitutionality of prison accommodation could not be judged simply on the basis of available floor space, "when floor space per prisoner diminishes to the extent that it has in South Africa, even the most reticent and cautious courts have ruled, on an adjudication of floor space alone, that prison conditions are degrading or cruel" (ibid). 
Clearly, Steinberg's research was conducted at a time of particular crisis in relation to overcrowding within South Africa's penal system. Despite the fact that the gravity of the problem has fluctuated over time, it has remained of serious concern to both the prison authorities and South Africa's leading penologists throughout the postapartheid period. The dogged persistence of this problem during the post-apartheid period is well illustrated in the following extract from a 2006 research report by Chris Giffard and Lukas Muntingh, in which they summarise trends in overcrowding within South Africa's prisons during the country's first decade of freedom:

The total number and proportion of prisoners living in prisons that are overcrowded have increased substantially since 1995. It is only the special remissions of 2005 that have brought some respite ... [E]ven though the proportion of prisoners living in conditions of between $100 \%$ and 200\% occupancy slowly decreased from 1996 to 2004 (a trend ended by the remission), this decrease has been at the expense of the proportion of prisoners living in conditions of occupancy rates more than 200\%: those detained in prisons which have more than twice as many prisoners than they were intended for increased from just $1 \%$ in 1995 to $36 \%$ in $2004 \ldots$.. Of equally great concern is the proportion of prisoners detained in institutions in which there are three times as many prisoners than capacity allows. There were no prisoners in this category until 1997, but by 2004 as many as $5 \%$ of all prisoners (a total of over 9000) were held such facilities. The special remissions reduced this number only slightly, to just less than $8500 .^{3}$

Prison overcrowding is not, however, solely a feature of the post-apartheid period. During the apartheid period, the problem plagued the National Party government and its prison authorities, providing those opposed to the apartheid system with the

3 See C Giffard \& L Muntingh The Effect of Sentencing on the Size of the South African Prison Population (Report commissioned by the Open Society Foundation for South Africa) 2006 at 64-65. See, also, in general, J Steinberg (n 2); J Redpath "Unsustainable and unjust - criminal justice policy and remand detention since 1994" (2014) 48 (June) SA Crime Quarterly at 25-37; C Ballard Research Report on Remand Detention in South Africa: An Overview of the Current Law and Proposals for Reform (Community Law Centre: University of the Western Cape, 2011); S Johnstone-Robertson, SD Lawn, A Welte, L-G Bekker \& R Wood "Tuberculosis in a South African prison: A transmission modelling analysis" (2011) 101(11) South African Medical $J$ at 809-813; D van Zyl Smit "Swimming against the tide: Controlling the size of the prison population in the new South Africa" in B Dixon \& E van der Spuy (eds) Justice Gained? Crime and Crime Control in South Africa's Transition (Cape Town, 2004) at 227-258; D van Zyl Smit "National report - South Africa" in D van Zyl Smit \& F Dünkel (eds) Imprisonment Today and Tomorrow - International Perspectives on Prisoners' Rights and Prison Conditions - Second Edition (Kluwer Law International, 2001) at 589-608; S Peté "The politics of imprisonment in the aftermath of South Africa's first democratic election" (1998) 1 South African J of Criminal Justice 51-83 (hereafter Peté "Politics"); S Peté "The good the bad and the warehoused - The politics of imprisonment during the run-up to South Africa's second democratic election" (2000) 13(1) South African J of Criminal Justice 1-56 (hereafter Peté "The good"); S Peté "Between the devil and the deep blue sea - The spectre of crime and prison overcrowding in post-apartheid South Africa" (2006) 27(3) Obiter 429-453 (hereafter Peté "Devil"). 
means to launch a series of ideological attacks on the apartheid regime. ${ }^{4}$ Aspects of the apartheid system clearly contributed to the problem of prison overcrowding during this period - for example the thousands of people imprisoned under the infamous pass laws. ${ }^{5}$ But the problem of prison overcrowding in South Africa did not start with the rise of apartheid. It can be traced back much earlier than this, to the very introduction of this form of punishment into South Africa by the colonial authorities. It is the aim of this article to examine just one of the four British colonies which were joined together to form the Union of South Africa in 1910, in order to illustrate the manner in which chronically overcrowded prisons, as well as countless debates on the problem, remained a feature of colonial life throughout the period during which the colony was in existence. The colony in question is the Colony of Natal and the period under examination is from the time of the introduction of British administration in 1845, following the annexation by the British Empire three years earlier in 1842, until the Union of South Africa came into existence in 1910. By shedding light on this one small part of South Africa's penal history, it is hoped that this article will contribute to a more nuanced understanding of the problem of chronic overcrowding in South African prisons. ${ }^{6}$ Part 1 of the article will cover the period 1845 to 1875 , while Part 2 will cover the period 1875 to 1910.

4 See, in general, S Peté "Holding up a mirror to apartheid South Africa - Public discourse on the issue of overcrowding in South African prisons 1980 to 1984 - Part One" (2014) 35(3) Obiter 485-505. See also Part Two of this article, which is due to be published in (2015) 36(1) Obiter. A clear indication of the continued severity of prison overcrowding in South Africa throughout both the apartheid and post-apartheid periods, is the fact that both periods are marked by a succession of "special amnesties" - colloquially known as "bursting" - designed to relieve pressure on an overstretched penal system. Giffard \& Muntingh (n 3) at 56-57 summarise the use of special amnesties to reduce severe overcrowding in South Africa from the early 1970s as follows: "In conditions of severe overcrowding (180\%) in 1971, about 13000 sentenced prisoners were given between three and six months amnesty. A further 28000 sentenced prisoners were released in 1981, and in total, nearly 88000 more between then and the first democratic elections in 1994 . Between 1994 and the end of 2000, a further estimated 49000 prisoners were released, including 8000 unsentenced prisoners who had been granted bail of less than R1000, and there were also amnesties for certain politically motivated violent offences. In 2005, a special remission of sentence was granted to prisoners who were serving sentences for non-violent offences. This eventuated in the release of nearly 32000 sentenced offenders, reducing the total prisoner population from an all-time high of 187000 to a more manageable $155000 . "$

5 See, in general, S Peté (n 4). Many must have hoped that the end of apartheid would bring an end to chronic overcrowding in the prisons, but as is indicated by the following comment in Feb 2013 by the Minister of Correctional Services, Sbu Ndebele, this was not to be: "That our offender population has remained constant, whether you remove pass laws, group areas, or apartheid laws, should make us search more urgently for answers to the high prison population in South Africa": see Mail \& Guardian Online available at http://mg.co.za/article/2013-02-11-south-africa-hashighest-prison-population-in-africa-says-ndebele (accessed 12 Feb 2013).

6 For an analysis of prison overcrowding in the context of the African continent as a whole, including a very brief summary of overcrowding in the prisons of colonial Natal, see S Peté "A brief history of human rights in the prisons of Africa" in J Sarkin (ed) Human Rights in African Prisons (Cape 


\section{Background and Early Years 1845-1860}

Any discussion of penal policy requires some understanding of the social, political and economic context within which that penal policy is shaped and implemented. The first point to be noted in relation to the penal policy of colonial Natal is that the annexation of Natal by the British in 1842 was carried out, primarily, to thwart the ambitions of Afrikaner Voortrekkers who were intent on establishing control over the area. It was with some reluctance that the Colony of Natal was added to the British Empire, since the British colonial authorities did not believe that the new colony held out much prospect of financial gain for the mother country. Because of this, the administration of the colony was conducted, by and large, "on the cheap", with the Imperial Government determined to keep costs to a minimum. ${ }^{7}$ As will be seen in the sections which follow, colonial officials stationed in Natal were forced, time and again, to plead with the Imperial Government in London for the necessary funds to build additional prison accommodation. These pleas were often either rebuffed by the Imperial authorities or else acceded to only in part, in a half-hearted and begrudging manner. The fact that the colonial state was permanently weak due to lack of sufficient finances was a major factor which shaped penal policy in the Colony of Natal and affected the degree of overcrowding in the gaols.

Another major factor which affected penal policy in colonial Natal was the relationship which existed between various political and economic interest groups in the colony. The most important of these interest groups was a large class of African subsistence farmers, who were essentially peasant producers engaged in the homestead system of production. ${ }^{8}$ The efficiency of this mode of production meant that peasant producers were well able to produce sufficient surplus to maintain their economic independence. To the British government, it made sound financial sense to retain the system of peasant production, since revenue obtained from these producers could offset expenditure in the new colony. The British government decided, therefore, to adopt a system of "indirect rule", as advocated by Theophilus Shepstone, who later became the Secretary for Native Affairs in the Colony. This allowed the consolidation of Zulu social structures within the colonial system and the continued existence of a strong class of peasant producers. ${ }^{9}$ Certain powerful economic interests within the

Town, 2008) 40-66 at 46-48 and 53-55. Further, for an analysis of prison overcrowding during the apartheid period, see, in general, S Peté (n 4). Finally, for an analysis of prison overcrowding during the post-apartheid period, see Peté "Devil" (n 3) at 429-453 passim.

7 See EH Brookes \& C De B Webb A History of Natal (Pietermaritzburg, 1965) at 29-41; D Welsh The Roots of Segregation - Native Policy in Colonial Natal 1845 to 1910 (Cape Town, 1971) at 7-9.

8 See J Guy "The destruction and reconstruction of Zulu society" in S Marks \& R Rathbone (eds) Industrialisation and Social Change in South Africa: African Class Formation, Culture and Consciousness 1870-1930 (New York, 1982) at 168-169; S Marks \& A Atmore Economy and Society in Pre-Industrial South Africa (London, 1980) at 113-114.

See Welsh (n 7) at 7-30. 
white ruling class were also in favour of the continued existence of the Zulu peasant producers. Among these were absentee speculators who owned large sections of land in the colony, and who found that the easiest way to make a profit was to allow the Zulu subsistence farmers to continue utilising the land in return for rent. ${ }^{10}$ Due to a desire to maintain trade, merchants in the colony were also inclined to support the continued existence of the Zulu subsistence farmers. With the Imperial government and several powerful economic interest groups on their side, the Zulu subsistence farmers in Natal were able to avoid becoming involved in wage labour for the white colonists for much of the nineteenth century.

The independence of the Zulu subsistence farmers was bitterly resented by the white farmers of the colony, since they were deprived of all the advantages which would be offered by cheap black labour. Over the years these white farmers and their allies waged a bitter struggle to narrow the options available to the black peasant producers, and so force them into the service on their farms. ${ }^{11}$ The white stock farmers of the interior were more strident in their views than the coastal sugar farmers, since the latter were somewhat pacified by the importation of Indian indentured labour, from 1860 onwards, to work on the sugar cane fields. According to Shula Marks, the stock farmers were inclined "to be far more radical in their views than the officials, planters, or townsmen" and they "regarded the failure of Africans to work for them virtually as a criminal offence". ${ }^{12}$ The white farmers desired a coercive labour system based on racial lines and sought every opportunity to secure a reliable supply of cheap black labour. In general, the social relations between the white colonists and the indigenous population of the colony were deeply coloured by the coercive nature of the economic relationships which the colonists wished to enforce over the reluctant black populace. Generally speaking, the ideology of the white colonists was dominated, on the one hand, by a deeply ingrained fear of the massive Zulu nation on their doorstep and, on the other hand, by racist paternalism towards the childlike black "savages" who needed to be "civilized" by the superior white race. ${ }^{13}$

The powerful mix of fear, racist paternalism, and extreme frustration at the reluctance of the indigenous inhabitants of Natal to become docile and obedient workers, was bound to influence ideologies of punishment within the colony. Whereas penal theory in Britain may have been based on the idea that offenders were to be rehabilitated by means of imprisonment within the so-called "separate system" - discussed further below - the social system of colonial Natal was based

10 See Brookes \& Webb (n 7) at 50-57. This practice was known by the racist term "Kafir Farming". See Marks \& Atmore (n 8) at 162-163.

11 See Marks \& Atmore (n 8) at 158-160.

12 See S Marks Reluctant Rebellion: The 1906-1908 Disturbances in Natal (Oxford, 1970) at 15, 17.

13 See S Peté \& A Devenish "Flogging, fear and food: Punishment and race in colonial Natal" (2005) 31(1) J of Southern African Studies 3-21; S Peté "Punishment and race: The emergence of racially defined punishment in colonial Natal" (1986) 1(2) Natal University Law and Society Review 99114. See, also, Marks (n 12) at 3-26. 
upon white domination, meaning that colonial penal theory sought to emphasise white sovereignty through the firm punishment of black offenders. In general, white colonial opinion favoured harsh corporal punishment and forced labour as forms of punishment suitable for black offenders, rather than imprisonment. The latter form of punishment was seen as a "humane" European-style of correction, which did not quite fit the realities of colonial society. Throughout the colonial period there was a conflict between the Imperial authorities on the one hand, constantly urging penal reform in order to bring the colony into line with "accepted penal practice", namely the best practice in England at the time, and the white colonists on the other, who complained bitterly and in racist terms that imprisonment had no effect on the idle and ignorant indigenes. To the white colonists in Natal, the officials in England who prescribed the "proper" forms of punishment for black offenders were guilty of a deeply misguided sentimentalism. The colonial state stood in the middle of these two ideological forces - on the one hand having to implement the instructions handed down by the Imperial authorities, and on the other hand having to resist political pressure brought to bear by the white colonists. Before Natal was granted responsible government status in 1894, the balance of power in this ideological conflict rested with the Imperial authorities, but thereafter it shifted in favour of the white colonists.

An important reason for overcrowding in the prisons of colonial Natal was an explosive growth of the prison population over the years of the colony's existence. One of the main reasons why Natal's prison population grew so rapidly, was the coercive nature of social relations - as sketched above - between the indigenous inhabitants of the region and the white colonists. Resistance on the part of the indigenous inhabitants led to the imprisonment of large numbers of Africans for petty offences. A significant reason for this was that, throughout the colonial period, prisons were used as a means of exercising social control over the indigenous population of the colony. ${ }^{14}$ In other words, Natal's gaols were, in general, overcrowded with offenders against social control legislation - such as the Masters and Servants Ordinance; the Pass Laws; and the Borough Bye Laws rather than with "criminals" in the true sense of the word. ${ }^{15}$ As was to happen a century later during the apartheid period,

14 This was to become a recurring theme in the penal history of South Africa as a whole. See, eg, in general, Peté (n 4).

15 See, in general, J Riekert The Natal Master and Servant Laws (unpublished LLM thesis, University of Natal: Pietermaritzburg, 1983). Similar processes were at work in other parts of the country. C van Onselen makes the following perceptive comment about the close inter-relationship between the mechanisms of economic coercion - in his example the mine compounds of the Witwatersrand - and the mechanisms of social coercion - namely the prisons: "[Economic forces] prised black South Africans off their land, separated them from their families, reduced them to the status of workers, and then ruthlessly reallocated them to the towns. There, on the bureaucratic leash of the pass laws, they were soon exposed to two sociologically similar institutions which served the 
countless numbers of ordinary black residents in the Colony became victims of the petty rules and regulations designed by the white colonists to keep control over the black population. Persons swept up in this dragnet of petty rules and regulations were often unable to pay the stipulated fines, and so ended up in the colony's overcrowded gaols. Many prisoners were not criminals but victims of economic forces beyond their control, forced to seek wage labour in towns or on farms controlled by the white colonists, before falling foul of the restrictive legislation designed to keep a tight rein on the black labour force, or some other petty measure aimed at the "protection" of white society. Sometimes low-level strife erupted into all-out war or rebellion - for example, the Langalibalele Rebellion of 1873; the Anglo-Zulu War of 1879; the Anglo-Boer War of 1899; and the Bambata Rebellion of 1906. Each of these events delivered a shock to the penal system of colonial Natal, and led to an influx of prisoners into already overcrowded prisons.

With the above as general background, we turn now to a few brief remarks on prison overcrowding in the first fifteen to twenty years of the colony's existence. Details of the birth of the prison in colonial Natal have been set out elsewhere and need not detain us here, apart from highlighting certain points relating to overcrowding. ${ }^{16}$ The first "prisons" in the colony - perhaps better described as lock-up houses - consisted of a few wattle-and-daub cottages, at least one purpose built by the Voortrekkers before the arrival of the British, but others simply rented from local residents. ${ }^{17}$ Initially, the number of offenders who had the misfortune to end up in one of these "gaols" was very low. For example, there were only five

rapidly industrialising economic system particularly well - the prisons and the mine compounds": see C van Onselen Studies in the Social and Economic History of the Witwatersrand 1886 to 1914 (Johannesburg, 1982) at 171.

16 For more details on the birth of the prison in colonial Natal, see S Peté "Falling on stony ground: Importing the penal practices of Europe into the prisons of colonial Natal (Part 1)" (2006) 12(2) Fundamina $100-112$ at 101-106.

17 The "Tronk" in Pietermaritzburg was described by AF Hattersley as "a wattle-and-daub structure, flanked with sod walls and surrounded by a pleasant garden, - not in the least suggestive of the rigours of prison life": see Portrait of a City (Pietermaritzburg, 1951) at 9-10. The Gaol in Durban, a wattle-and-daub building rented from a certain Mr Dand in 1849 (the previous lockup having been rented from a Mr Benningfield in 1847), was described by the Natal Witness as "a low cottage, overgrown with creepers, fronted by a thick, verdant and lofty hedge". See 18 Apr 1851 Natal Witness. Despite these idyllic descriptions, life for inmates could clearly be unpleasant. One of the earliest complaints about prison conditions in Natal came from a group of ten traders who were locked up in the Pietermaritzburg "Tronk" in 1842 when the Boers were still in charge of the town. They complained to the Boer Commandant-General inter alia as follows: "We humbly submit to you and hope you will take into consideration and kindly ease us of being chained during the day and of the intolerable stench caused by our being obliged to ease ourselves inside the Tronk, this with being confined with closed windows which may soon cause a disease fatal to us and perhaps spread through the whole town." See E Goetzche The Father of a City: The Life and Times of George Cato, First Mayor of Durban (Durban, 1967) at 47-48. 
prisoners in the Pietermaritzburg Gaol in February $1846 .{ }^{18}$ As the years went by, however, the number of prisoners began to rise and the accommodation provided by the rustic cottages became increasingly inadequate. For example, in February 1859, Lieutenant-Governor Scott described the Pietermaritzburg Gaol as "in every respect unsuited for the present wants of the Colony" and informed the Imperial authorities in London that "there is now a pressing need for better provision being made for prisoners, not only in Pietermaritzburg, but also in Durban and elsewhere". ${ }^{19}$ On 3 June 1861, in his opening address to the Legislative Council, the LieutenantGovernor alluded to the fact that growth in the Colony had resulted in "our great deficiency in prison accommodation", which he described as "more and more conspicuous amongst the pressing requirements". ${ }^{20}$ Although the construction of purpose built prisons to replace the wattle-and-daub structures of earlier times began in the first half of the 1860s, certain gaols remained dilapidated and overcrowded well into this period. ${ }^{21}$ As late as February 1864, for example, the Durban gaoler reported that thirty-six prisoners were forced to occupy the seven rooms which were available in the antiquated gaol. Racial segregation was firmly in place within the Durban Gaol at this time, with white prisoners being kept apart from black prisoners. As was to be expected in a colony dominated by racist ideology, white prisoners were shielded from the very worst effects of the overcrowding. According to the Durban Gaoler, whilst a particular room in the gaol might accommodate as many as nine black prisoners, "there would not be more than six white men in such a room". ${ }^{22}$ It is clear, therefore, that the general suffering inflicted on prisoners due to severely overcrowded conditions, was much harsher in the case of black prisoners than their white counterparts.

\section{Chronic Overcrowding and the Failure to Introduce the "Separate System" into the Penal System of Colonial Natal in the 1860 s and early 1870 s}

An enduring theme within the discourse surrounding imprisonment in colonial Natal during the 1860s and early 1870s was a series of calls by the Imperial authorities in England, directed at the Government of Natal, to introduce the so-called "separate

18 Irish University Press Series of British Parliamentary Papers - Colonies Africa (Shannon, 1971) vol 28 Natal at 65: West to Maitland, 24 Feb 1846. Martin West had taken up his duties as the first Lieutenant-Governor of Natal in Dec 1845.

19 NAB (KwaZulu-Natal Pietermaritzburg Archives Repository) Colonial Office (London) 179/51: Scott to Lytton, 4 Feb 1859.

207 Jun 1861 Natal Witness.

21 Construction of a new Central Gaol in Pietermaritzburg was begun in Jan 1861, while construction of a new gaol in Durban only started in Nov 1864. See 22 Nov 1864 Natal Witness.

22 NAB CSO (Colonial Secretary's Office, Natal) 196/327: Report of Durban Gaoler, 12 Feb 1864. 
system" into the gaols of the colony. ${ }^{23}$ These calls were, however, doomed to failure as a result of the ever increasing prison population, as well as scepticism on the part of the white colonists in general. For the latter, although the "separate system" might be necessary in the punishment of "European" offenders, who needed to be rehabilitated before they could be re-accepted into the fold of white colonial society, in the case of "non-European" offenders the lessons needed could be taught most effectively by the cat-ò-nine-tails, as well as by forced productive labour for the colonial state and/or for white colonial society in general. In the eyes of the white colonists, who lived in a society stratified along strict racial lines and dominated by racist ideology, "rehabilitation" for the latter category of prisoners consisted in knowing who was the "master" and who the "servant", as well as in understanding that the economic future of "non-Europeans" lay in wage labour for the white man.

The insistence of the Imperial authorities that the "separate system" be introduced into the gaols of colonial Natal was based upon what was at the time believed to be "best practice" in the treatment and rehabilitation of offenders in England. During the 1860s an extensive and widespread investigation was conducted by the Imperial authorities in order to determine whether or not the various penal practices of the many British colonies conformed to the model provided by the penal practices of the mother country. In 1863, two reports were sent to the colonies describing what was believed to be the "state of the art" in relation to methods of punishment. ${ }^{24}$ The purpose of sending these reports to the colonies was clearly to enable the colonies to copy these state of the art methods.

In 1865, questionnaires were sent to all British colonies in order to gather information on the different penal practices which were in operation across the Empire. The information received was used to compile what came to be known as the "Digest and Summary of Information respecting Colonial Prisons" (hereafter referred to as the Digest). ${ }^{25}$ Two principles which were particularly stressed in the Digest were the principle of "strictly penal labour" - for example, non-productive labour on a "treadwheel" or "crank" or at "shot drill" - and the principle of strict separation of prisoners, one from another - the "separate system" - which was regarded as fundamental to prison discipline ${ }^{26}$ The inescapable implication of the

23 For a more general discussion of the penal reforms proposed by the Imperial authorities during the period 1865 to 1867, including in particular the issue of penal labour, see Peté (n 16) at 107-111.

24 These reports were the "Report of the Committee of the House of Lords on the State of Discipline in Gaols" and the "Report of the Royal Commission on Penal Servitude". See NAB Government House, Natal 359/2: Circular Despatch Newcastle to Scott, 19 Oct 1863; and NAB Government House, Natal 358/162: Circular Despatch Newcastle to Scott, 19 Aug 1863.

25 See NAB Imperial Blue Book - Digest and Summary of Information Respecting Colonial Prisons (drawn up and presented to the British Parliament by Command of Queen Victoria in 1867, C3961 of 1867) at 4: Circular Despatch Cordwell to Maclean, 16 Jan 1865.

26 For details on the introduction of strictly penal labour into the prisons of colonial Natal, see Peté (n 16) at 100-112; S Peté "Falling on stony ground: Importing the penal practices of Europe into the prisons of Colonial Natal - Part Two" (2007) 13(2) Fundamina 111-125. 
latter principle for prison accommodation was that a sufficient number of cells had to be built so as to allow each prisoner be confined in a separate cell. ${ }^{27}$ Clearly, in a financially strapped colony such as Natal where the prisons were already overcrowded, this was always going to be a tall order. What made it even more difficult was the fact that the white colonists saw no good reason to treat African prisoners in the same manner that "European" prisoners were treated in England. For their part, the Imperial authorities remained resolutely wedded to the principle of separation. ${ }^{28}$

The response of the authorities in Natal to the insistence of the Imperial authorities in London that the principle of separation as set out in the Digest be implemented in the colony, was very negative. ${ }^{29}$ There were not nearly enough cells in the penal system to allow prisoners to be kept apart at night, and during the day most prisoners worked together in gangs on public works. In any event, most colonists believed that the "separate system" would be wasted on "non-European" prisoners, who were not so much in need of being rehabilitated into society, as in need of a swift harsh lesson as to who was in charge of the colony - namely the white colonists - and what the role of "non-Europeans" in the colony actually was - namely to provide a source of cheap labour for the white colonists. ${ }^{30}$ To the colonial mind, the "separate system" only made sense if it meant reserving separate cells for white prisoners. In other words, in the overcrowded conditions of a colonial prison, a single cell was something of a "luxury" for selected (white) prisoners, rather than a necessity for all prisoners.

On 19 November 1868 a Commission of Enquiry was appointed to investigate the reform of Natal's penal system. The Commission confirmed that it was impossible to carry out the separate system in either the Durban or the Pietermaritzburg Gaol,

27 M Ignatieff Just Measure of Pain (New York, 1978) at 102 describes the attraction of the "separate system" to prison authorities in England as follows: "Solitary confinement was designed to wrest the governance of prisons out of the hands of the inmate subculture. It restored the state's control over the criminal's conscience. It divided convicts so that they would lose the capacity to resist both in thought and action."

28 They clearly believed the following principal stated in the Digest: "It has been recognised too long and too widely to be now disputed that good discipline is impracticable and corruption certain where prisoners are in communication with each other, and that separation is the only basis for a sound penal system." See NAB Imperial Blue Book - Digest and Summary of Information Respecting Colonial Prisons (drawn up and presented to the British Parliament by Command of Queen Victoria in 1867, C3961 of 1867) (n 25) at 65 IV.

29 See, eg, NAB Colonial Office, London 179/89: Keate to Buckingham, 6 May 1868: Enclosure Report of Colonial Engineer, 26 Dec 1867.

30 A good example of the general rejection of the "separate system" by the colonial authorities is the following opinion of the Colonial Engineer that the separate system would not be "particularly advantageous in the case of Kafirs and Coolies who form the great majority of prisoners in Natal. Provision for enforcing this system, however, in particular cases and especially amongst persons of European blood is very desirable ...": see NAB Colonial Office, London 179/89: Keate to Buckingham, 6 May 1868: Enclosure - Report of Colonial Engineer, 26 Dec 1867. 
because of lack of accommodation. In the Pietermaritzburg Gaol at this time, seven cells were occupied by twenty-two white prisoners, whereas forty black prisoners were forced to live in only ten cells. ${ }^{31}$ Furthermore, due to financial constraints, there was not much hope of more prison accommodation being built. The Commission pointed out that "in the present financial state of the Colony there is no probability that new gaols would be constructed". ${ }^{32}$

The situation did not improve over the years which followed. In 1872 the Durban Gaol was overcrowded to such an extent that only 176 cubic feet of space was available for each prisoner. The Digest laid down that 900 cubic feet of space per prisoner was suitable for prisoners in England, while even more space was necessary in tropical climates. ${ }^{33}$ This was the lowest figure of all the Natal gaols and compared very unfavourably with the figure for the Pietermaritzburg Gaol, namely 696 cubic feet per prisoner. ${ }^{34}$ Overcrowding had many adverse effects; for example, since there was no infirmary at the Durban Gaol, the general overcrowding resulted in the cells which were allocated to sick prisoners also being overcrowded. On 5 November 1872, in a chilling comment, the Durban Gaol Board stated that "in some cases it is to be feared that life has been sacrificed for want of proper accommodation for the sick". ${ }^{35}$ Of course, with the overcrowding in Natal's gaols, it was impossible to introduce the separate system, although the Imperial authorities continued to urge that this problem be rectified. ${ }^{36}$ On 30 July 1873 the Secretary of State, Lord Carnarvon, expressed his concern at the lack of prison accommodation in Natal and recommended that the Lieutenant-Governor give the matter his "early and serious consideration". ${ }^{37}$ Within a few months of this despatch being sent, the problem of chronic overcrowding in the two central gaols of the colony was to become worse than ever, as these gaols were flooded with "rebel" prisoners who were captured and incarcerated following the "Langalibalele Rebellion" of 1873.

31 NAB CSO 324/304: Evidence of Superintendent Pietermaritzburg Gaol to Commission of Enquiry appointed on 19 Nov 1868.

32 Idem at 3.

33 NAB Imperial Blue Book - Digest and Summary of Information Respecting Colonial Prisons (drawn up and presented to the British Parliament by Command of Queen Victoria in 1867, C3961 of 1867) (n 25) at 84 XVI.

34 NAB Natal Blue Book, 1872: AA8 point IV.

35 NAB CSO 424/2228: Meeting of Durban Gaol Board, 5 Nov 1872.

36 The Natal Blue Book for 1872 stated as follows: "None of the prisons are on the separate system. The separation enforced, where the gaol accommodation admits of it, is that of sexes and races. Prisoners on remand are also, where practicable, kept apart from convicted prisoners. All male prisoners sentenced to hard labour are worked in association." See NAB Natal Blue Book, 1872: AA8 point I.

37 Government House Natal 58/Despatch 350 KwaZulu-Natal Archives Pietermaritzburg Archives Repository: Kimberley to Pine 30 Jul 1873. 


\section{The Langalibalele Rebellion of 1873 and its Effect on Prison Overcrowding}

An infrequent yet important factor contributing over the decades to chronic overcrowding in the prisons of colonial Natal was the outbreak, from time to time, of war or serious rebellion within the colony. An important example of one such "rebellion" was the so-called "Langalibalele Rebellion" of 1873 which led to the imprisonment of a large number of African "rebels" in prisons of the colony. Clearly, the "rebels" were not "criminals" in the strict sense of the word. This being the case, it was inappropriate for them to be confined in gaols of the colony, which were already bursting at the seams with conventional "criminals". After both the Langalibalele Rebellion and the Bambata Rebellion, the Natal governmental authorities took steps to keep the "rebels" out of the penal system. Each rebellion will be examined in turn.

The events which came to be known as the "Langalibalele Rebellion" took place towards the end of 1873. Langalibalele was the chief of the Hlubi tribe which occupied land in the foothills of the Drakensberg mountains near Champagne Castle and Cathkin Peak. Following a dispute with the local magistrate over unregistered guns in the possession of his tribesmen, Langalibalele ignored an order to report in person to the authorities in Pietermaritzburg. In the eyes of the authorities this amounted to open rebellion. A force consisting of 200 British troops, 300 colonial volunteers, and 6000 African tribesmen was sent to quell the "insurrection". During the ensuing battle, between 150 and 200 of the Hlubi were killed. Langalibalele and one of his sons were banished to Robben Island and 200 Hlubi tribesmen were imprisoned. $^{38}$

The increase in the prison population due to the sudden influx of "rebel" prisoners placed great strain on Natal's already overcrowded gaols. On 30 December 1873, the Pietermaritzburg Gaoler reported that he had been forced to confine the "rebel" prisoners as follows:

... 24 in the carpenter's shop, 12 in a tent and 9 in a small shed, making in all 45 in the Gaol yard. ${ }^{39}$

He pointed out that "the rebel chief may be expected soon, and the confinement of prisoners in the Gaol yard is to say the least dangerous ..." ${ }^{40}$ Forty-eight prisoners were transferred to Durban to make room for the "rebel" prisoners, and five additional staff members were appointed at the Durban Gaol to cater for the increase in the prison population. ${ }^{41}$ Langalibalele was subsequently confined in the Pietermaritzburg Gaol for a time, amid intense speculation on the part of the local African population

38 Brookes \& Webb (n 7) at 113-123.

39 NAB CSO, 459/3127: Superintendent Pietermaritzburg Gaol to Colonial Secretary, 30 Dec 1873.

40 Ibid.

41 NAB CSO 460/97: Superintendent Durban Gaol, 8 Jan 1874. 
that he would escape somehow. This speculation was caused by two unusual natural phenomena which happened to occur at this time, namely an eclipse of the sun, followed by a fierce hailstorm. According to the Natal Witness the local African population believed both these phenomena to be the work of Langalibalele. ${ }^{42}$ The eclipse was seen as an attempt by Langalibalele to bring total darkness to the earth, under cover of which he might be rescued by his followers. He was believed to have caused the hailstorm in an attempt to break open the roof of the gaol in which he was imprisoned. Needless to say, neither Langalibalele nor any of the imprisoned Hlubi tribesmen were able to escape. The overcrowded conditions in the prisons remained of major concern to the authorities at the time.

One of the consequences of the Langalibalele Rebellion was the passing of Law 18 of 1874, with the following self-explanatory title: "To make Special Provision with regard to the Employment of Convicts" ${ }^{43}$ Under this law the Lieutenant Governor was authorised to assign any convict who had been sentenced to hard labour, as a servant to any private individual or to the Colonial Engineer, for the term of his sentence. ${ }^{44}$ The Lieutenant Governor in Executive Council was empowered to frame rules and regulations for carrying out the new Law, and on 10 April 1874 a set of such rules and regulations was promulgated in the Government Gazette. ${ }^{45}$ The rules and regulations laid down not only the rights and duties of the "European employer" and the "native convict" who had been assigned to him, but also made provision for the convict's family. ${ }^{46}$ Family members were permitted to reside with the convict on the land of his employer. ${ }^{47}$ The employer was required to provide both the convict and his family with food and lodging. ${ }^{48}$ In return, the employer could demand the services of any unmarried female who was over ten years of age and any male who was over twelve years of age, who belonged to the convict's family and

421 May 1874 The Natal Witness.

43 Law 18 of 1874 (Natal) "To make Special Provision with regard to the Employment of Convicts".

44 It is interesting to note that there had been a failed attempt to pass similar legislation just over a decade earlier in 1863. In that year a Bill was proposed which sought to give the Lieutenant Governor the power to "permit any person undergoing any sentence of imprisonment to become the servant or apprentice of any house-holder applying for the same ...". (See GN 56 Government Gazette, Natal of 21 Apr 1863: Bill "For the Employment of Prisoners on Public Works" at s 10.) Prisoners so assigned were to be subjected to the provisions of the Masters and Servants Ordinance Number 2 of 1850 (idem at s 11). However, the punishment for desertion was to be more severe for prisoners assigned as servants, than the punishment for desertion by "normal" servants under the Masters and Servants Ordinance. Prisoners who deserted their masters were to be punished by up to two years' additional punishment plus, at the discretion of the resident magistrate, up to fifty lashes (idem at s 7). The Bill was rejected by the Legislative Council and never became law. (See 17 Jul 1863 The Natal Witness "Legislative Council 8 July 1863".)

45 NAB Executive Council Vol 9 at 258; and NAB Colonial Office, London 179/117: Pine to Carnarvon, 22 Feb 1875 - Enclosure 1: Government Notice 117 of 1874.

46 Ibid.

47 Idem: Regulation 1.

48 Idem: Regulation 2. 
were residing with the convict on the employer's land. Males over eighteen years of age who belonged to the convict's family and were residing with the convict on the employer's land, were not free to work elsewhere until such time as the convict's period of assignment had expired. ${ }^{49}$ This did not apply, however, if the employer was unwilling to employ such males and pay them wages equivalent to the going rate at the time. In terms of the regulations, family members were to be remunerated "at such rate of wages as shall in each case be fixed by the magistrate, taking into account the obligations of the employer". ${ }^{50}$

With regard to the convict, the employer was to be entitled to his services "at all reasonable times" and his wages were to be fixed by the magistrate. ${ }^{51}$ These wages were not to be paid directly to the convict, except by direction of the Lieutenant Governor. ${ }^{52}$ In the normal course of events all such wages were to be paid into an account entitled "The Convict Relief Fund". ${ }^{53}$ The Lieutenant Governor was authorised to

draw upon such fund for the purpose of relieving from want or rewarding for good conduct, or for the purpose of enabling any native convict on expiration of the period of imprisonment to acquire the means of re-establishing himself in the Colony: Provided that in no case shall the amount so granted for relief, reward, or otherwise, exceed the aggregate amount of wages earned by the said convict during his imprisonment. ${ }^{54}$

Law 18 of 1874 was aimed at black political offenders, namely "rebels", who had resisted white domination rather than at "criminals" in the true sense of the word. This is apparent from the circumstances under which the Law was framed and the contents of the Law itself.

Following the Langalibalele Rebellion, 200 tribesmen were imprisoned. Clearly these men were not criminals from whom society would have to be protected, and who would have to be rehabilitated before they could take up their place in society. They were "rebels", political offenders, and once the rebellion had been broken, a punishment was needed which would be sufficiently severe yet would not involve imprisonment, since the prisons were already overcrowded with "real" criminals. In other words, the law had been used as an instrument of political oppression. The penal system was not suitable for dealing with political offenders. In the eyes of the white colonists, Law 18 of 1874 clearly provided the ideal punishment for "rebels", namely compulsory labour for the benefit of the white man. As pointed out earlier in this article, a major theme of the political economy of Natal throughout the colonial period was the constant struggle by the white colonists to force the African tribesmen

49 Idem: Regulation 5.

50 Idem: Regulation 3.

51 Ibid.

52 Idem: Regulation 9.

53 Idem: Regulation 12.

54 Idem: Regulation 13. 
into wage labour on white farms. Indeed, certain white farmers viewed the failure of the African tribesmen to work on their farms as tantamount to a criminal offence. To these white colonial farmers, forcing "rebels" into wage labour on white farms was a fitting punishment for those who had dared to challenge white sovereignty. Of course, such punishment would not have been suitable for "criminals" in the strict sense of the word, such as murderers, rapists, thieves and so on. On 21 April 1874, The Natal Witness, commenting on the rules and regulations promulgated under Law 18 of 1874, stated that since strong opposition was to be expected from "English negropholists", perhaps it would be better to treat offenders such as Langalibalele's 200 "rebels" as ordinary criminals. ${ }^{55}$ As hard labour prisoners they could be employed in the construction of much needed public works. The Natal Witness found it difficult to understand why the "Exeter Hall mind ... would rather the Kafirs endured penal servitude, than that they should be restored to their families and be required to work for white employers at fair wages". ${ }^{56}$

Clearly the reason was that the authorities in England feared that, since Law 18 of 1874 was designed to deal with political offenders, it would be used as a means of political oppression. As an official in the Colonial Office in London remarked:

If the law is intended to apply really to convicts condemned to hard labour, fancy assigning 20 criminals to a farmer without any provision either for his protection or their discipline, while if it is intended to be applied as it really is to political offenders it must inevitably be used as an instrument of oppression. ${ }^{57}$

In his Despatch of 29 April 1875, the Secretary of State, Lord Carnarvon, informed the Lieutenant Governor that Law 18 of 1874 had been disallowed. The following reasons were given for the step that had been taken:

On a sudden emergency, such as lately arose, where it was imperatively necessary to make instant provision for feeding a large number of prisoners, and the resources of the Government were inadequate for the purpose of lodging and keeping them, such a course as assigning natives for a short period to those who would provide properly for them, might be defensible as a temporary measure resorted to under pressure; but to take a general power of assigning convicts as private servants, would open a door to many objectionable practices, owing, among many other causes, to the impossibility of properly supervising either the employers or the employed. ${ }^{58}$

5521 Apr 1874 The Natal Witness.

56 Ibid.

57 NAB Colonial Office, London 179/117: Pine to Carnarvon, 22 Feb 1875: Minute by Colonial Office official, 7 Apr 1875.

58 NAB Government House, Natal 64/Despatch 57: Carnarvon to Wolseley, 29 Apr 1875 at par 3. 


\section{Conclusion}

Throughout the period dealt with in part one of this article, chronic overcrowding remained a pressing problem in the gaols of colonial Natal. Starved of adequate financial resources, the colonial state was unable to provide sufficient prison accommodation to cater for the number of inmates confined within the system. The problem was aggravated by the fact that the prisons were used as a method of social control over the indigenous population of the Colony. Furthermore, as illustrated by the Langalibalele Rebellion, the penal system was vulnerable to external shocks caused by war and civil strife, which greatly increased the number of prisoners requiring accommodation. Finally, the problem of overcrowding in the prisons of colonial Natal came with a nasty racial twist. Due to socio-economic circumstances prevailing in the Colony and the peculiar nature of the racist ideology which dominated white colonial society, most white colonists did not regard imprisonment as a particularly suitable form of punishment for black offenders, preferring harsh corporal punishment combined with forced labour in service of the colonial state and/ or white society in general. The result was that conditions were always considerably more overcrowded for "non-European" prisoners than for "European" prisoners in the gaols of colonial Natal. These themes will be further explored in part two of this article, which will examine the period from 1875 until the end of the colonial period in 1910 .

\section{ABSTRACT}

During recent decades, like the proverbial bad penny, the problem of chronic overcrowding has turned up over and over again to haunt South African prison administrators. As this article indicates, however, overcrowding in South African prisons is not only a recent phenomenon. Overcrowding has been a significant feature of imprisonment in South Africa from the very introduction of this form of punishment into the country. This article examines overcrowding in the prisons of colonial Natal from 1845 until 1910. Through an analysis of the official discourse surrounding this difficult problem throughout the colonial period, this article shows that imprisonment as a form of punishment in South Africa has always been inextricably bound up with the problem of overcrowding. By illustrating the deeply entrenched nature of the problem from a historical perspective, this article hopes to provide present-day prison administrators with useful insights into the nature of their struggle to overcome the problem. The article is in two parts. Part 1 of the article covers the period 1845 to 1875 , while Part 2 covers the period 1875 to 1910 . 